\title{
Small fruit breeding in Finland
}

\author{
HEIMO HIIRSALMI \\ Agricultural Research Centre, \\ Department of Horticulture \\ SF-21500 Piikkiö, Finland
}

\begin{abstract}
In Finland, the breeding of small fruits has been focused on species belonging to the Ribes, Fragaria, Rubus, Vaccinium and Hippophaë genera.

Of the blackcurrant, many local varieties have been brought under cultivation during this century, the most significant being 'Brödtorp' and 'Melalahti'. The Department of Horticulture of the Agricultural Research Centre has, by means of intervariety crossings, developed selections combining high yield, upright growth and resistance to gooseberry mildew. A selection with green berries, chosen from among the self-pollination progeny of the Swedish 'Öjebyn' variety, was released for cultivation in 1987, under the name 'Vertti'. As to the gooseberry, the old Finnish varieties 'Hinnnomäen keltainen' and 'Lepaan punainen' are still generally cul-
\end{abstract} tivated.

In 1984, the Department of Horticulture released the late, cultivated strawberry variety 'Hiku', a very good cropper, for cultivation. It comes from the crossing 'Senga Sengana' $x$ 'Redgauntlet'. The most promising early selection, which this spring was released for cultivation under the name 'Mari', comes from the crossing 'Pocahontas' $x$ 'Lihama'. In 1986, the wood strawberry variety 'Minja' a result of the crossing Fragaria vesca x 'Rügen', was brought under cultivation.

In the breeding of the raspberry, the Department of Horticulture has utilized the gene pools of wild raspherries; this has produced new selections with fairly good winter hardiness. This spring a variety named 'Ville', which was produced in the crossing of the Canadian 'Ottawa' and a Finnish wild raspberry strain, was introduced on the market. In addition, the raspberry has been crossed with the arctic bramble. By means of many crossings and back-crossings, the so-called nectar raspberry was developed, of which the variety 'Heija' was released for cultivation in 1975 and the variety 'Heisa' in 1981.

Of the arctic bramble, two natural strains selected by the North Savo Research Station of the Agricultural Research Centre were brought under cultivation in 1972 under the variety names 'Mesma' and 'Mespi'. The cross between them, 'Pima', was released for cultivation in 1982. By crossing the arctic bramble with the Alaska bramble, the Department of Horticulture has developed arctic bramble hybrid selections, two of which were named varieties, 'Aura' and 'Astra', in 1986. They form a higher growth structure than the arctic bramble, are better croppers and have bigger berries with the fine aroma of the arctic bramble.

As a result of the breeding work done at the Department of Horticulture, a highbush blueberry variety, 'Aron', with a better winter hardiness than the foreign varieties, was released for cultivation in 1982. It comes from the back-crossing 'Rancocas' x (Vaccinium uliginosum $x$ 'Rancocas'). 
The aim of the breeding of the sea-buckthorn at the Department of Horticulture is, by means of crossings between subspecies growing wild in Europe and Asia, to reduce the thorniness of the bushes and to cause the berries to come off the stalks intact. The release of two selections for cultivation is presently being prepared.

Index words: berry plant breeding, breeding of the currant, breeding of the strawberry, breeding of the raspberry, breeding of the arctic bramble, breeding of the highbush blueberry, breeding of the sea-buckthorn

\section{Introduction}

The small fruits that do well under Finnish conditions constitute a fairly heterogeneous whole, which includes both domestic wild species and species imported from abroad. Rarely do they as such meet the requirements of different spheres of interests, and even though they may be well enough suited for cultivation, it is now possible to improve many characteristics by means of breeding methods.

Plant breeding must be regarded as a fundamentally important division of horticultural research. Along with the research into cultivation techniques, plant breeding holds a key position in ensuring development in the field of horticulture. In the horticultural sector, active breeding work has been done in Finland on top fruits, small fruits and ornamentals, among which it is more difficult to find varieties developed abroad that are suitable for cultivation here than, for example, among vegetable annuals. Since its founding in 1927, the programme of the Agricultural Research Centre's Department of Horticulture has included, among other things, trials with small fruits and has centred its breeding operations particularly on this group of plants, paying special attention to the conditions prevailing in the Nordic countries. The breeding of small fruits done by others in Finland has remained limited and sporadic.

At the Department of Horticulture there was a period of ten years when no actual plant breeding was done. However, already during its first few years of operation, the department acquired numerous varieties of various small fruit species, the thriving potential of which was then monitored. These preliminary observations laid the foundations on which the necessary variety trials still rest today. On the basis of these, over the years the Department of Horticulture has been able to recommend numerous varieties for actual cultivation. Knowledge of the foreign variety material is essential for planning and implementing breeding operations on the national and local levels.

The first true breeding trials with small fruits were carried out at the Department of Horticulture in 1939 and 1940. It was the first time raspberry was crossed with the arctic bramble, producing a tetraploid blackcurrant. This was the beginning of the breeding of the nectar raspberry and the blackcurrant. In addition to these, important subjects for breeding have been the strawberry, the raspberry, the arctic bramble, the highbush blueberry and the sea-buckthorn.

\section{On the methods of breeding work}

At the Department of Horticulture we have applied to small fruits the methods found to be generally useful in plant breeding; classic plant breeding, interspecific breeding, heterosis breeding, polyploidy breeding and mutation breeding.

The oldest form of conscious plant breeding, the classic plant breeding, is based on the variation caused by the natural intraspecific variability found in the plant material. On adapting wild small fruit species to cultivation, strains with advantageous characteristics have been chosen for clone tests. On the other 
hand, with small fruits under cultivation, through intraspecific crossings and selection, we have tried to develop individuals combining the desired characteristics.

Interspecific breeding with small fruits has been employed to produce new hybrid species suitable for cultivation. In the purest sense this means crossing parental forms that are genetically different to such an extent that disturbances are found in the meiotic divisions of the crosses, and these disturbances often cause at least partial sterility of the crosses. Then again, due to the ambiguity of the concept of species, some plants classified as different species can cross with each other just as easily as intraspecific forms do. Here interspecific breeding does not differ essentially from classic breeding. If the fertility of the interspecific crosses is low, it may in some cases be improved by producing an $\mathrm{F}_{2}$-generation.

Even if the $F_{1}$-generation created as a result of interspecific breeding is completely sterile, the third breeding method, polyploidy breeding, may prove helpful. With the allotetraploid forms induced by colchicine treatment, the balancing of the chromosomes can restore fertility. On the other hand, with small fruits it has been possible to produce also autotetraploid forms, the development of which has not, however, led to significant practical applications.

As a result of the cross-breeding between varieties as well as between species, a certain objective may be attained in a relatively short time, with small fruits in as little as ten years. The objective is, however, attained with greater probability by using the methods offered by heterosis breeding, i.e. repeated self-pollinations with selected individuals and combination crossing between the pure lines thus obtained. The desired end result with perennial small fruits is then several decades away, however.

Mutation breeding is used to increase the variability of the plants by inducing artificial changes. To achieve this goal, a programme has been set up with certain small fruits, in which seeds, cuttings or seedlings are treated with $\mathrm{x}$-rays, the aim being to produce favourable gene or chromosome mutations.

\section{On the objectives of breeding work}

Definitions of the objectives of breeding work should take into account the requirements of the growers, the sellers, the processing industry and consumers already at a stage when species and varieties are chosen for breeding and when breeding programmes are being planned.

Important issues from the grower's point of view are climatic and pedologic suitability, the yield and quality of the crop, as well as its resistance to disease and pests. In recent years, especially the mechanization of harvesting, has also made new demands of the breeders, demands which are often difficult to fulfil. The sellers of the produce, on the other hand, are concerned about how well the product stands up to transport and keeps in storage. The processing industry has its own specialized requirements, which are often focused on matters arising from chemical composition. Important aspects as far as berries are concerned include a certain acid and aroma content, a high vitamin C content, as well as a certain colour and colour fastness. Today's consumers, particularly concerning berry plants, take an active interest even in new types of products. This gives the researcher greater freedom to use, for instance, interspecific breeding.

\section{Breeding with different small fruit genera}

The genetics-based breeding of small fruits was introduced to Finland by Professor Olavi Meurman with the Ribes and Rubus species in 1939 and 1940 at the Department of Horticulture of the Agricultural Research Centre at Piikkiö. The results obtained were highly positive, proof of which are the tetraploid blackcurrant and the cross between the raspberry and the arctic bramble. Subsequently, the breeding work done at the Department of Horticulture has been intensi- 
fied, and has included species from the following small fruit genera: Ribes, Fragaria, Rubus, Vaccinium and Hippophaë.

The other research units, where objectiveoriented breeding of small fruits has been done, include the Agricultural Research Centre's research station at Maaninka in North Savo and the South Savo Research Station in Mikkeli as well as the Department of Plant Breeding of the University of Helsinki, at Viikki. The arctic bramble of the Rubus genus was the subject of breeding at Maanin$\mathrm{ka}$ in the 1960s and in Mikkeli in the 1970s, and it is still included in the breeding programme at Viikki, where in recent years the blackberry has also received attention.

Ribes L. - In Finland, several domestic local varieties of blackcurrant, R.nigrum L., have been under cultivation; they are most probably the result of spontaneous mutations. The oldest of them, being exceptionally good croppers with big berries, were taken note of already in the last century. Of the old varieties chosen for cultivation, especially 'Brödtorp', ‘Ảström' and 'Kajaanin musta' deserve mentioning; the important newer ones include 'Lepaan musta', 'Gerby', 'Melalahti' and 'Hangaste' (Meurman 1947, SäKö 1973). The 'Brödtorp' variety, which comes from somewhere in the archipelago of Finland proper or the Åland islands, was until the 1970s the most commonly grown variety in Finland. It is well known for its delicious berries, but also for its creeping growth and susceptibility to gooseberry mildew (Sphaerotheca mors-uvae (Schw.) Berk.), for which reason it has been ousted by other varieties, especially the Swedish local variety 'Öjebyn'. Of the varieties mentioned above, the 'Melalahti', originating at Paltamo in the Kajaani region, has, with its upright growth and mildew resistance, become increasingly important to blackcurrant cultivation in northern Finland.

As to the gooseberry, R.grossularia L., the conscious breeding started in the beginning of this century (Meurman 1947). As the result of the work done by B.W. Heikel and G. Collan, particularly at the Hinnonmäki ex- perimental station at Lepaa, several gooseberry varieties were released for cultivation by the 1920s. Of these, 'Hinnonmäen keltainen' and 'Lepaan punainen' are still today the most commonly grown gooseberry varieties in Finland, as they are resistant to mildew, though they do not produce big berries.

The first breeding trials at the Department of Horticulture were done in the summer of 1939. The seedlings of various blackcurrant varieties were treated with colchicine. The trials were continued in the summer of 1940, when visible results were already achieved. According to the personal communication of Pohjanheimo, the growing point of the young seedling was treated with one drop of an aqueous solution of $1 \%$ colchicine $3-5$ times for a few days. The surviving plants showed a clear colchicine effect. Some of them proved to be tetraploid. All the species of the Ribes genus were previously invariably diploid, $2 \mathrm{n}=16$ (Meurman 1928). This being the case, producing a tetraploid blackcurrant can be considered a most significant achievement.

The morphologically new autotetraploid blackcurrant differed greatly from the diploid plant (VAarama 1947). The increase that had occurred in the size, breadth and thickness of the different plant parts deserve particular mention. The fertility, on the other hand, showed a marked decrease which was clearly due to meiotic disturbances. In addition to quadrivalents, univalents, bivalents and trivalents and even higher chromosome associations were also found. The meiotic disturbances of the autotetraploid blackcurrant were also reflected in the progeny generations as aneuploidy (VAARAMA 1949 b, 1953). There were individuals that lacked either one chromosome or had one or two more than normally, $2 n=32$. This caused disturbances in the somatic divisions, e.g. abnormalities in the formation of the nuclear spindle (VAARAMA 1948 a, 1949 b). The effect of colchicine appeared as permanent changes, in part even in those individuals that had remained diploid (VAarama 1949 a). The work on the tetraploid forms of the blackcurrant was regrett- 
ably discontinued before any practical applications had been made, nor has there been any opportunity to start it up anew since then.

In Finland, actual interspecific breeding has received only minor attention as regards the Ribes genus. Yet since 1950, the Department of Horticulture has carried out crossings between gooseberry and blackcurrant varieties, which, however, have not led to practical applications. In the recently started breeding of red- and whitecurrants, varieties with a different specific origin have been crossed. In this way we are endeavouring to utilize the gene pools of at least four species: R.rubrum L., R.spicatum Robs., R.petraeum Wulf. and R.multiflorum Kit.

Since 1961, the breeding work done on the Ribes genus at the Department of Horticulture has been focused mainly on the blackcurrant. The aim has been to improve not only the size and quality of the yield but also the characteristics important for mechanized harvesting - first for harvesting using shakers, and now for machine-harvesting. The main target of improvement is the growth habit of the shoots. Crossing of the domestic highyield but creeping 'Brödtorp' variety with Central European and British upright-growing varieties has produced a satisfactory result with a number of high-yield, upright-growing and winterhardy selections.

Gooseberry mildew, however, began as early as in the 1960s to pose a serious problem to the cultivation of the blackcurrant. Most of the foreign varieties were susceptible to the disease (Rousi 1966 a). The mildew fungus is transformed all the time, new strains are generated. More and more varieties, including 'Brödtorp' and the new promising selections, were contaminated by gooseberry mildew. Only two varieties, the Swedish local varieties 'Matkakoski' and 'Sunderbyn II' are known to be resistant to all current mildew strains. These two, as well as especially two varieties with field resistance to mildew, the Swedish 'Öjebyn' and the Finnish 'Melalahti', have often been used as a parent in intervariety crossings. The most promising, in terms of high yield, upright growth and field resistance to gooseberry mildew, has proved to be the selection chosen from the crossing done in 1967 between 'Öjebyn' and the British 'Wellington XXX'. It will be proposed as a variety for cultivation.

In the breeding of the blackcurrant, the methods of heterosis breeding have also been applied. Ever since 1961, self-pollinations have been made with some varieties in order to produce pure lines in terms of yield, upright growth and resistance to gooseberry mildew. With the varieties 'Brödtorp' and 'Lepaan musta', we have shifted to the fifth selfpollination generation; by means of combination crossings we are now aiming at a result that will serve practical needs.

Self-pollination of some varieties, e.g. 'Öjebyn', the most commonly grown variety in Finland, regularly produces a certain number of progeny individuals, whose berries are yellowish green when ripe. This is probably due to a recessive gene which, being homozygous, prevents anthocyanin synthesis (JUNNILA and Hitrsalmi 1987). A selection with green berries, chosen from among the self-pollination progeny of the variety 'Öjebyn', was released for cultivation in 1987 under the variety name 'Vertti' (JunNILA et al. 1987).

Fragaria L. - The cultivated strawberry, the hybrid species Fragaria x ananassa Duch., such as it is grown today, is entirely a product of plant breeding. It is a spontaneous cross between two octoploid American species, the F.virginiana Duch. and the F.chiloensis (L.) Duch., which was generated under cultivation. Subsequently, the cultivated strawberry has been the subject of much active breeding work, and it has become one of the most important cultivated berry plants in the world.

Over the decades the cultivation value of over one hundred strawberry varieties bred abroad has been worked out through the services of the Department of Horticulture. However, only a few of these are being cultivated in Finland, where the most important varieties at present are 'Senga Sengana', 'Zefyr' and 'Jonsok'. 
However, Finnish agriculture cannot afford to be based solely on foreign varieties continuously. Each country and each breeding establishment does, in fact, work mainly with local conditions in mind. The emergence of a variety like 'Senga Sengana', which has attained global cultivation, is extremely rare.

In Finland, the systematic breeding of the strawberry is still young. The breeding work based on crossing, which started at the Department of Horticulture in 1961, is first and foremost aimed at the development of industrial varieties. On the other hand, we are trying to produce early varieties, the berries being suited primarily for use fresh.

The development of new strawberry varieties should pay attention especially to the size of the yield and the berries as well as to the firmness of the berries, their ability to withstand transport and to their properties when frozen, their acid, aroma and vitamin content, their flavour, colour and shape. Further important qualities include resistance to various diseases and pests, with special reference to grey mould and powdery mildew as well as to strawberry mite and eelworm. The development of varieties suitable for mechanized harvesting has become a current consideration. Here the prerequisite is, among other things, a ripening of the berries that is as simultaneous as possible.

Based on the evaluation of cross progenies of the strawberry, the Department of Horticulture has so far picked up a total of 9,500 seedlings whose culture value has been tested in a number of trials. One of these selections was released for cultivation in 1984 under the variety name 'Hiku' (HırRSAlmı and SÄKÖ 1985). It originates from the crossing 'Senga Sengana' $x$ 'Redgauntlet'. This new variety of cultivated strawberry has proved to possess valuable characteristics: it is a very good cropper and the berries are large and of good quality. Its open growth habit promotes resistance to grey mould and powdery mildew. 'Hiku' is classified in Finland as a late variety, and thereby it is not suited for cultivation in the northern part of the country.
The most promising early selection, which in the spring 1988 was released for cultivation under the name 'Mari', comes from the crossing 'Pocahontas' $x$ 'Lihama'. It shares many of its characteristics with the early variety 'Zefyr'; as to resistance to powdery mildew it is superior to the latter.

The wood strawberry, Fragaria vesca L., and its perpetual-fruiting form, the month strawberry, Fragaria vesca L. var. semperflorens (Duch.) Ser., cross easily. As a result of the crossing in 1968 of a domestic wood strawberry strain with the German month strawberry variety 'Rügen' a selection, which in 1986 was released for cultivation under the variety name 'Minja' was produced at the Department of Horticulture (Hirrsalmi et al. 1987 b). The wood strawberry variety 'Minja' has a vigorous growth and produces a multitude of runners. The flowers and the berries form above the leaves. The major part of the crop in southern Finland is ready for harvesting in July and at the end of August, but the berries ripen until the beginning of September. This variety can be regarded as a perpetual-fruiting variety. The aromatic berries, which during the summer yield about $300 \mathrm{~g}$ per metre of row, are small in size. 'Minja' is especially suited for domestic growth.

Rubus L. - The objective of the interspecific breeding of the raspberry, $R$.idaeus L., and the arctic bramble, R.arcticus L., initiated in 1939 at the Department of Horticulture, has been to develop a berry plant combining the aroma of the arctic bramble, particularly well suited for use by the liqueur and juice industry, with the advantageous cultivation qualities of the raspberry. The first crossing trials with a raspberry variety, the origin of which remains unknown, produced four seeds, one of which germinated. The smallest possible $F_{1}$-generation thus created has since been vegetatively propagated time and again. In order to produce several $\mathrm{F}_{1}$-cross individuals, work towards this end has been done nearly every year. As a result, one seedling was produced both in 1973 and in 1977. In both instances the pistillate plant was a natural 
strain of the arctic bramble, Tervaranta, which comes from Maaninka in Savo, and the pollinator was a Canadian raspberry variety, 'Ottawa'.

As to most of the external characteristics, e.g. growth habit, colour of the flowers and appearance of the leaves, all the cross clones are intermediate forms of the raspberry and the arctic bramble. This is also true of the aroma of the berries. Unfortunately, however, they are almost sterile, even though the sterility seems to be due to only minor meiotic disturbances (VAARAma 1948 b, 1951). The main cause is that the stamen another and the pollen suffer from dryness during summer, making fertilization impossible. Some fruits developed in autumn, when the air humidity increases. This phenomenon, which has been transmitted from the arctic bramble (Hirrsalmi 1975, Hirrsalmi et al. 1987 a), is called seasonal sterility.

From among the $\mathrm{F}_{2}$ - and $\mathrm{F}_{3}$-generations produced as a result of free pollination, a number of selections, with promising yield, berry size and aroma have been chosen. They have come to be called nectar raspberries. The arctic bramble aroma has been found to be most prominent in an individual of the $\mathrm{F}_{3}$-generation, which has been given the name Merva. Regrettably its yield has been so low that it has been impossible to use Merva for general cultivation.

By crossing the raspberry variety 'Malling Promise' with Merva, promising selections have been obtained, of which two varieties have been released for cultivation: 'Heija' in 1975 and 'Heisa' in 1981 (Hurssalmi and SÄKö 1976, 1981). They resemble the raspberry in terms of vegetative and cultivation characteristics. Studies on aromatic substances have shown that the berries of both varieties have approximately the same amount of the favourable aromatic substances typical of the arctic bramble (HIIrSAlmi et al. 1974, PyysaLo 1976). They contain very little of the unfavourable aromatic substances of the raspberry, ionones. 'Heisa' is a better variety than 'Heija' in terms of growth habit, winter hardi- ness as well as cropping and berry size. It yields a crop size nearly as large as 'Ottawa', which is the most widely grown raspberry variety in Finland.

The obstacle to more widespread cultivation of the raspberry in Finland is the fact that the varieties developed abroad are very poorly suited to Nordic climatic conditions. They suffer winter damage for many years; sometimes the damage is so serious that there is no crop at all. Comparative field cultivation trials carried out by the Department of Horticulture have made it eminently clear that the wild raspberry strains collected in Finland are better in terms of winter hardiness that the cultivated varieties. The wild raspberries, however, are not suitable as such for actual cultivation since, among other things, their berries are small and the crop level remains low. By crossing natural raspberry strains that combine advantageous characteristics with the best cultivated varieties it has been possible to transfer these valuable characteristics - above all winter hardiness - to the latter. The selection chosen from the crossing between the 'Ottawa' variety and a natural raspberry strain originating at Hautjärvi, Mäntsälä, has been definitely more winterhardy than the others. It has produced a satisfactory crop, and its berries have been found to be aromatic though rather small. This selection was put on the market under the name 'Ville' in the spring 1988.

As a result of the research initiated in the 1930s at the North Savo Research Station of the Agricultural Research Centre at Maaninka and continued since the 1970 s at the South Savo Research Station in Mikkeli, many issues pertaining to the ecology, morphology, pollination relationships and fruiting as well as to the cultivation technique of a valuable wild berry, the arctic bramble, have been cleared up (RYYNÄNEN 1973). This species has proved to be self-sterile; in order to fruit it, the arctic bramble should be in a mixed population of two more clones (TAMmisOla and RYYNÄNEN 1970). With a view to field cultivation of the arctic bramble, two clones generated from 
natural strains were simultaneously released for sale in 1972; they were given the variety names 'Mesma' and 'Mespi' (RYynÄNEN 1972).

The breeding of the arctic bramble was at first limited to just comparing and choosing strains collected from nature. Later, crossings were made between some of the best strains, and in 1982 a third arctic bramble variety 'Pima' was brought under cultivation. It is a better cropper and culture-wise safer than the earlier ones: the improvements have been achieved by crossing two of the above varieties (RYYNÄNEN and Dalman 1983). All three varieties, however, have a number of characteristics hindering financially profitable cultivation. The varieties are low-growing. Their berries are small, the colour is prone to changes, and they take a long time to ripen. The yield shows considerable annual fluctuations, and it mostly remains low. Furthermore, these varieties are self-sterile.

In order to improve the qualities for cultivation, the arctic bramble has been crossed with the Alaska bramble, which grows wild in the Bering Sea area. The first crossings were made in Sweden in the 1950s, in Finland in the early 1970 s by the Department of Horticulture (LARSSON 1969, 1980 a, 1980 b, HilrSALMI and SÄKö 1980). The Alaska bramble, which must be considered a subspecies, $R$.arcticus L. subsp. stellatus (Sm.) Boiv., forms a higher growth structure than the arctic bramble. Its berries are larger and firmer than those of the arctic bramble, but they do not have the aroma typical of the arctic bramble.

In 1986, two arctic bramble hybrid selections were released for cultivation under the variety names 'Aura' and 'Astra' (HurRsalmı et al. 1987 a). They were chosen from among the progeny raised from free-pollination seeds of the Alaska bramble, which were sent to the Department of Horticulture in 1968 by the Öjebyn experimental station in Sweden. The pollinator was some natural strain of the arctic bramble that grew in the same trial field as the self-sterile Alaska bramble clone. The plant that came out of the crossing has been given the name R.arcticus $\mathrm{L}$. subsp. x stellarcticus by G. Larsson (LARSSON 1980 a). The shoots of the 'Aura' and 'Astra' varieties are sturdier and taller than those of the arctic bramble. In addition, these varieties have a vigorous growth and produce a great number of shoots. Both varieties, and especially 'Aura', in the field trials have given considerably bigger crops than the arctic bramble varieties. They have inherited the large firm berries of the Alaska bramble and the fine aroma of the arctic bramble. Unfortunately, like their progenitors, both varieties are self-sterile.

Vaccinium L. - As a result of the breeding operations started in 1908 and 1909, one of the most important cultivated plants of the United States, the highbush blueberry, has been developed here. As initial material was used all the bush-like species V.australe small and V.corymbosum L. and the dwarf shrublike species V.lamarckii Camp. Plants of ten different highbush blueberry varieties were procured for the Department of Horticulture in spring 1947. The best in comparative trials have so far proved to be 'June' and 'Rancocas’ (HiIrSAlmı and SÄKö 1973).

The results obtained in the experimental cultivation of the highbush blueberry in Finland have not, however, been good enough to warrant practical applications. All the varieties are susceptible to winter damage and to blueberry cancer, caused by the fungus Fusicoccum putrefaciens Shear. In order to develop varieties better suited to Nordic climatic conditions, since 1961 the breeding operations at the Department of Horticulture have involved efforts to cross the domestic species Vaccinium with highbush blueberry varieties. Of the North European species, the bog blueberry, V.uliginosum L., with the same tetraploid chromosome number $(2 n=48)$ as the highbush blueberry, has been successfully crossed with the latter (Rousi 1963, HirRSAlmi 1977).

The $\mathrm{F}_{1}$-cross progenies of the bog blueberry and the highbush blueberry obviously have disadvantageous gene combinations that are typical of a cross between two widely separated species, combinations which in due 
course will cause disturbances. They are manifested as a lessened vigour, followed by a decrease in winterhardiness and yield. Consequently, we have not been albe to find a single individual in the $\mathrm{F}_{1}$-cross progenies that would be of use in actual berry growing. The course of action aimed at utilizing the genes of the bog blueberry in the breeding of the highbush blueberry has been continued by carrying out successful back-crossings with highbush blueberry varieties. Then the unfavourable gene combinations have at least partly been broken up, and a number of rather promising individuals have been produced. Of these the selection found to be the most winterhardy was released for cultivation in spring 1982 under the variety name 'Aron' (Hirrsalmi and Lehmushovi 1982).

The highbush blueberry variety 'Aron' was chosen in 1965 from among the progeny of the back-cross 'Rancocas' $\mathrm{x}$ (bog blueberry $\mathrm{x}$ 'Rancocas') produced at the Department of Horticulture. As to vegetative characteristics, it is closer to the highbush blueberry than to the bog blueberry. The bush reaches a height of about $1 \mathrm{~m}$. The winter hardiness and resistance to blueberry cancer of this variety are clearly better than those of the foreign varieties. The vigorous bushes produce a satisfactory crop at least under the climatic conditions of southern Finland; the calculated yield has come to about $30 \mathrm{~kg} / 100 \mathrm{~m}^{2}$ a year. The berries are medium-sized, $100-130 \mathrm{~g} / 100$ berries, and they are of good quality, sweet and aromatic. They are suitable for use fresh and for freezing.

The domestic blueberry, the bilberry, V.myrtillus L., and the lingonberry, V.vitisidaea $\mathrm{L}$., have also been tried for breeding purposes. Tetraploid individuals of the bilberry have been produced by means of colchicine treatment (Rousı 1966 b). Their use has not, however, brought about any result. The bilberry and the lingonberry cross produces a viable, though only poorly fertile, cross species $V . \times$ intermedium Ruthe (LeHMUSHOV and Hirrsalmi 1976). Its meiosis is heavily disturbed (Rousı 1967). In addition, it has not yet been possible to produce a tetraploid form of it. The Department of Horticulture has collected natural strains of the lingonberry and the cranberry, V.oxycoccos L. The strains best suited for cultivation among them may be proposed as varieties.

Hippophaë L. - The sea-buckthorn, H.rhamnoides L., is a dioecious wild berry, which does very well also under field conditions. The berries have a high vitamin $\mathrm{C}$ content, and delicious juice and liqueur can be made from them. The harvesting of the berries is difficult, however, preventing profitable cultivation. By means of various breeding measures, attempts have been made to reduce the thorniness of the bushes and, on the other hand, to cause the berries to come off the stalk intact.

The first step in the breeding of the seabuckthorn was in the early 1960s to procure seeds for the Department of Horticulture from different parts of the area of distribution of the species, u.e. from Europe and Asia. Cytological and morphological studies showed that the H.rhamnoides species includes several subspecies (Rousi 1965, 1971). By crossing these, progenies have been produced, from which a number of pistillate and staminate individuals have been chosen for comparative trials. Two selections are at present being prepared for release for cultivation. Of these, the pistillate plant originates from a crossing, where a natural strain from the Caucasus mountain system (H.rhamnoides L. subsp. caucasica Rousi) was pollinated with a Finnish strain from Saloinen (H.rhamnoides L. subsp. rhamnoides), and the staminate plant correspondingly from a crossing, where a Finnish strain from Ii (H.rhamnoides L. subsp. rhamnoides) was pollinated with a strain from the Hiddensee island in the GDR (H.rhamnoides L. subsp. rhamnoides).

In the Soviet Union, where the sea-buckthorn is being cultivated, several varieties with very thinly scattered thorns have been developed. The comparative trials done at the Department of Horticulture have included eight Siberian varieties since 1981 . They were, 
however, seriously damaged during the severely cold winter of 1986-1987. The Finnish natural strains and the crosses made by the Department of Horticulture, on the other hand, for the most part escaped damage. The aim of the breeding of the sea-buckthorn done at the Department of Horticulture is to utilize the advantageous characteristics of the varieties from the Soviet Union.

\section{References}

Hırsalmı, H. 1975. Koe pölyttäjien, ilman kosteuden ja lämpötilan vaikutuksesta mesimarjan marjontaan. Puutarhantutk.lait. Tiedote 1: 18-23.

- 1977. Inheritance of characters in hybrids of Vaccinium uliginosum and highbush blueberries. Ann. Agric. Fenn. 16: 7-18.

-, JunNila, S. \& SÃKö, J. 1987 a. 'Aura' and 'Astra', Finnish arctic bramble hybrid varieties. Ann. Agric. Fenn. 26: 261-269.

-, Junnila, S. \& Säkö, J. 1987 b. 'Minja', a Finnish wood strawberry variety. Ann. Agric. Fenn. 26: $271-274$.

-, Kallio, H., Pyysalo, T., Linko, R. \& Koponen, P. 1974. The ionone content of raspberries, nectarberries and nectar raspberries and its influence on their flavour. Ann. Agric. Fenn. 13: 23-29.

— \& Lehmushovi, A. 1982. A Finnish highbush blueberry variety 'Aron'. Ann. Agric. Fenn. 21: 151-154.

— \& SAKÖ, J. 1973. Variety trials with the highbush blueberry in Finland. Ann. Agric. Fenn. 12: 190-199.

— \& SĂкÖ, J. 1976. The nectar raspberry, Rubus idaeus $\mathrm{x}$ Rubus arcticus - a new cultivated plant. Ann. Agric. Fenn. 15: 168-174.

— \& SÄко, J. 1980. Hybrids of the arctic bramble species (Rubus stellatus x R.arcticus). Acta Hort. 112: 103-108.

— \& SĀKo, J. 1981. 'Heisa' - a new nectar raspberry variety. Ann. Agric. Fenn. 20: 268-272.

— \& SĀKO, J. 1985. A Finnish strawberry variety 'Hiku'. Ann. Agric. Fenn. 24: 179-182.

JunNila, S. \& HirRsalmi, H. 1987. Genetic background of green fruit colour in blackcurrant. Ann. Agric. Fenn. 26: $275-278$.

-, Hirrsalmi, H. \& Sãkö, J. 1987. A green-fruited blackcurrant variety 'Vertti'. Ann. Agric. Fenn. 26: 279-283.

LARSSON, G. 1969. Experimental taxonomy as a base for breeding in Northern Rubi. Hereditas 63: 283-351.

- 1980 a. Rubus arcticus L. subsp. x stellarcticus subsp. nov. Bot. Not. 133: 227-228.

- 1980 b. Rubus arcticus L. subsp. x stellarcticus, a new arctic raspberry. Acta Hort. 112: 143-144.

Lehmushovi, A. \& Hirrsalmi, H. 1976. Mustikan ja puolukan risteytymän, Vaccinium $\mathrm{x}$ intermedium Ruthe, Porin esiintymă. Puutarhantutk.lait. Tiedote 7: $24-45$,
Pyysalo, T. 1976. Studies on the volatile compounds of some berries in genus Rubus, especially cloudberry ( $R u$ bus chamaemorus L.) and hybrids between raspberry (Rubus idaeus L.) and arctic bramble (Rubus arcticus L.). Techn. Res. Centr. Finl. Materials and Processing Technology, Publ. 14. Espoo.

Meurman, O. 1928. Cytological studies in the genus Ribes L. Hereditas 11: 289-356.

- 1947. Suomen hedelmäpuut ja viljellyt marjat. II. Päärynät, luumut, kirsikat ja marjat. 351 p. Helsinki.

Rousı, A. 1963. Hybridization between Vaccinium uliginosum and cultivated blueberry. Ann. Agric. Fenn. 2: $12-18$.

- 1965. Observations on the cytology and variation of European and Asiatic populations of Hippohaë rhamnoides. Ann. Bot. Fenn. 2: 1-18.

- 1966 a. A probable case of monogenically determined resistance to American gooseberry mildew in blackcurrant. Ann. Agric. Fenn. 5: 256-259.

-1966 b. The use of North-European Vaccinium species in blueberry breeding. Acta Agric. Scand. Suppl. 16: $50-54$.

- 1967. Cytological observations on some species and hybrids of Vaccinium. Züchter 36: 352-359.

- 1971. The genus Hippophaë L. A taxonomic study. Ann. Bot. Fenn. 8: 177-227.

RYYNĀNEN, A. 1972. Arctic bramble (Rubus arcticus L.), a new cultivated plant. Ann. Agric. Fenn. 11: 170-173.

- 1973. Rubus arcticus L. and its cultivation. Ann. Agric. Fenn. 12: 1-76.

- \& Dalman, P. 1983. A new variety of arctic bramble 'Pima'. Ann. Agric. Fenn. 22: 1-7.

SÃKÖ, J. 1973. Variety trials with blackcurrant conducted in Finland. Ann. Agric. Fenn. 12: 113-125.

TAMmISOLA, J. \& RYYNÃNEN, A. 1970. Incompatibility in Rubus arcticus L. Hereditas 66: 269-278.

VAarama, A. 1947. Morphological and cytological studies on colchicine-induced tetraploid Ribes nigrum. Acta Agr. Fenn. 67: 55-93.

- 1948 a. Cryptic polyploidy and variation of chromosome number in Ribes nigrum. Nature 162: 782.

- 1948 b. Cytogenetic studies on two Rubus arcticushybrids. J. Agric. Sci. Finl. 20: 67-79.

- 1949 a. Permanent effect of colchicine on Ribes nigrum. Proc. 8th Int. Congr. Genet. Stockholm. Hereditas, Suppl. 1949: 680-681. 
- 1949 b. Spindle abnormalities and variation in chromosome number in Ribes nigrum. Hereditas 35: $136-162$.

- 1951. Om artkorsningsförädling inom släktet Rubus. Nord. Jordbr.forskn., 8. Kongr., Häfte 2-3: 412-
417.

- 1953. The effect of aneuploidy upon the progeny of an autotetraploid Ribes nigrum. J. Sci. Agric. Soc. Finl. 25: $77-83$.

\section{SELOSTUS}

\section{Marjakasvien jalostus Suomessa}

\section{Heimo Hiirsalmi}

\section{Maatalouden tutkimuskeskus, puutarhaosasto 21500 Piikkiö}

Marjakasvien jalostus on Suomessa kohdistunut Ribes-, Fragaria-, Rubus-, Vaccinium- ja Hippophaë-sukuihin kuuluviin lajeihin. Maatalouden tutkimuskeskuksen puutarhaosastolla on suunnitelmallista jalostustoimintaa tehty jo vuodesta 1939 lăhtien ottaen erityisesti huomioon Pohjoismaissa vallitsevat olosuhteet. Muiden tahojen Suomessa harjoittama marjakasvien jalostus on ollut varsin văhăistă ja satunnaista. Uusia jalosteita kehitettāessă erityisesti huomioitavia ominaisuuksia ovat satoisuus, sadon laatu ja sen korjattavuus, ilmastollinen ja maaperällinen soveltuvuus sekä taudin- ja tuholaiskeståvyys.

Mustaherukasta on tämän vuosisadan aikana otettu viljelyyn suuri joukko paikallislajikkeita, merkityksellisimpină 'Brödtorp' ja 'Melalahti'. Maatalouden tutkimuskeskuksen puutarhaosastolla on vuodesta 1961 alkaen lajikkeiden vălisin risteytyksin kehitetty jalosteita, joissa yhtyvăt satoisuus, pystykasvuisuus ja karviaishärmänkestăvyys. Ruotsalaisen 'Öjebyn'-lajikkeen itsepölytysjälkelăistöstă valittu vihreămarjainen jaloste on vuonna 1987 laskettu viljelyyn nimellä 'Vertti'. Karviaisella ovat vanhat suomalaiset lajikkeet 'Hinnonmăen keltainen' ja 'Lepaan punainen' edelleen yleisessă viljelyssă.

Lajikkeiden vălisiin risteytyksiin perustuva mansikan jalostus käynnistettiin puutarhaosastolla vuonna 1961. Työn tuloksena laskettiin vuonna 1984 viljelyyn erittäin satoisa myöhäinen hyötymansikkalajike 'Hiku'. Se on peräisin risteytyksestä 'Senga Sengana' $x$ 'Redgauntlet'. Risteytyksestä 'Pocahontas' $x$ 'Lihama' on syntynyt lupaava aikainen jaloste, joka kevaaallä 1988 laskettiin viljelyyn lajikenimellä 'Mari'. Vuonna 1986 saatiin viljelyyn risteytyksen Fragaria vesca x 'Rügen' tuloksena ahomansikkalajike 'Minja'.

Vadelman jalostuksessa on puutarhaosastolla hyödynnetty luonnonvadelmien geenivaroja ja saatu năin syntymaaăn jokseenkin talvenkestäviă uusia jalosteita. 'Ottawa'-lajikkeen ja luonnonvadelmakannan välisestä risteytyksestă syntynyt aromikkaita joskin pienehköjä mar- joja tuottava jaloste laskettiin keväăllä 1988 kauppaan lajikenimellä 'Ville'. Vadelma on lisäksi kyetty risteyttämään mesimarjan kanssa. Monien risteytysten ja takaisinristeytysten kautta on kehitetty ns. mesivadelma, josta on laskettu viljelyyn kaksi lajiketta, vuonna 1975 'Heija' ja vuonna 1981 edellistă talvenkestăvămpi ja satoisampi 'Heisa'.

Mesimarjasta on Maatalouden tutkimuskeskuksen Pohjois-Savon tutkimusasemalla valittu kaksi luonnonkantaa, jotka on vuonna 1972 otettu viljelyyn lajikenimillä 'Mesma' ja 'Mespi'. Niiden risteytymä 'Pima' laskettiin viljelyyn vuonna 1982 . Viljelyominaisuuksien parantamiseksi on mesimarja risteytetty Beringinmeren alueella kasvavan alaskanmesimarjan kanssa. Näin syntynyt kasvi on saanut nimen jalomaarain. Puutarhaosasto on vuonna 1986 nimennyt kaksi jalomaarainlajiketta 'Aura' ja 'Astra'. Ne muodostavat mesimarjaa korkeamman kasvuston, ovat satoisampia ja suurempimarjaisia; marjoissa on mesimarjan hieno aromi.

Amerikkalaisen pensasmustikan koeviljelystä Suomessa saadut kokemukset eivăt ole johtaneet käytännön sovellutuksiin, sillă kaikki ulkolaiset lajikkeet ovat varsin alttiita talvivaurioille ja mustikkasyöpătaudille. Paremmin pohjoisiin ilmasto-oloihin sopeutuvien lajikkeiden kehittämiseksi puutarhaosastolla on vuodesta 1961 lähtien pyritty risteyttämaaăn kotimaisia Vaccinium-lajeja pensasmustikkalajikkeiden kanssa. Jalostustyön tuloksena laskettiin vuonna 1982 viljelyyn ulkolaisia lajikkeita talvenja taudinkestăvămpi pensasmustikkalajike 'Aron'. Se on peräisin takaisinristeytyksestä 'Rancocas' x (Vaccinium uliginosum x 'Rancocas').

Puutarhaosastolla suoritettavan tyrnin jalostuksen tavoitteena on Euroopassa ja Aasiassa luonnonvaraisena kasvavien alalajien vălisin risteytyksin văhentăă pensaiden piikkisyyttä ja vaikuttaa siihen, ettă marjat irtoavat eheinả kannasta. Kahden jalosteen viljelyyn laskua valmistellaan parhaillaan. 


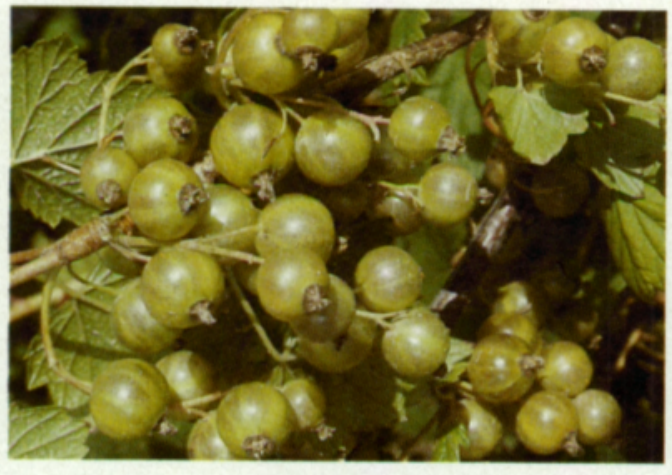

Fig. 1. The green-fruited blackcurrant variety 'Vertti'.

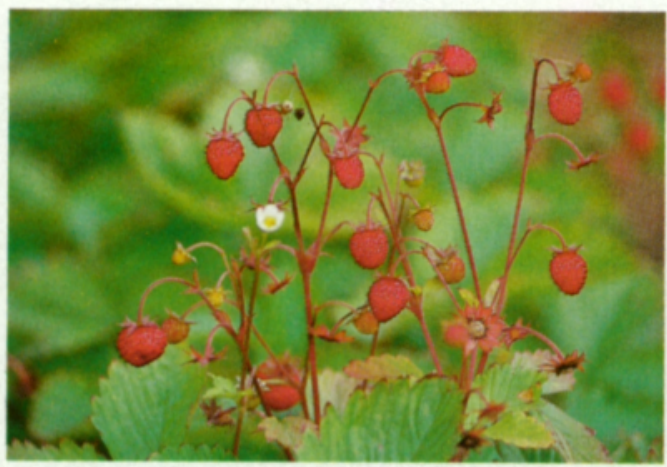

Fig. 3. The wood strawberry variety 'Minja'.

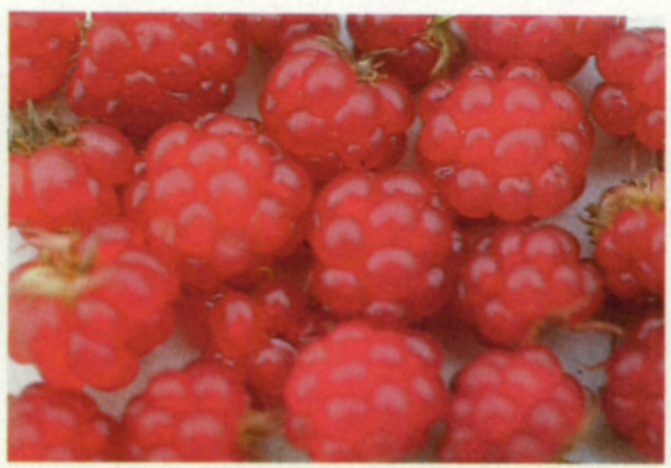

Fig. 5. The arctic bramble hybrid variety 'Aura'.

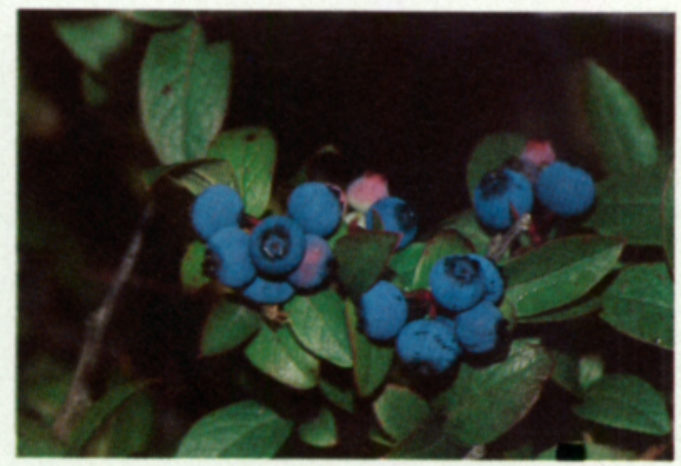

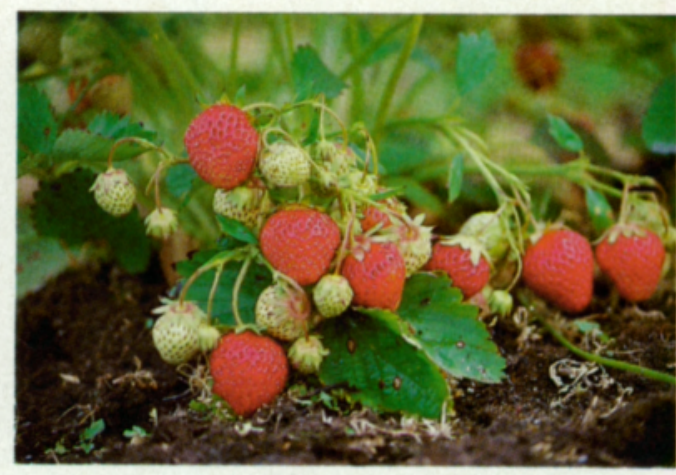

Fig. 2. The strawberry variety 'Hiku'.

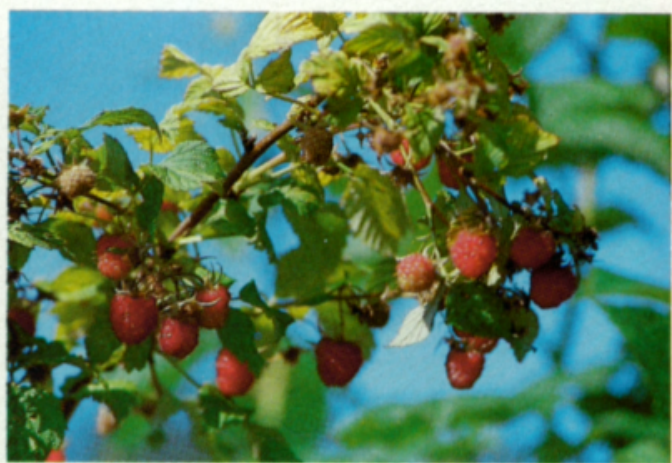

Fig. 4. The nectar raspberry variety 'Heisa'.

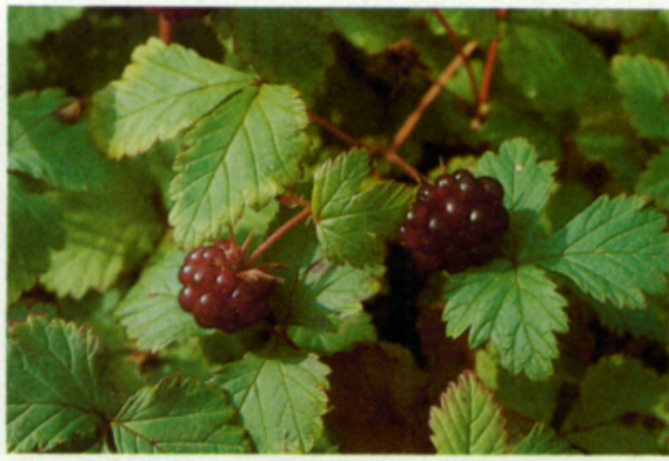

Fig. 6. The arctic bramble hybrid variety 'Astra'.

Fig. 7. The highbush blueberry variety 'Aron'. 